Check for updates

Cite this: RSC Adv., 2017, 7, 54460

Received 19th October 2017

Accepted 16th November 2017

DOI: $10.1039 / \mathrm{c} 7 \mathrm{ra11540g}$

rsc.li/rsc-advances

\section{Nano-composite of $\mathrm{CO}_{3} \mathrm{O}_{4}$ and $\mathrm{Cu}$ with enhanced stability and catalytic performance for non- enzymatic electrochemical glucose sensors}

\begin{abstract}
Xiaoyun Lin, (D) *a Yanfang Wang, ${ }^{a}$ Wenhui He, ${ }^{a}$ Yongnian Ni (D) *ab and Serge Kokot ${ }^{c}$
Nanostructured $\mathrm{CO}_{3} \mathrm{O}_{4}$ with near-cubic morphology was synthesised using the solvothermal method, and a non-enzymatic electrochemical glucose sensor $\left(\mathrm{CO}_{3} \mathrm{O}_{4}-\mathrm{CuNPs} / \mathrm{Pt}\right)$ was successfully constructed by dropping and potentiostatic depositing technologies. The obtained $\mathrm{CO}_{3} \mathrm{O}_{4}$ and $\mathrm{CO}_{3} \mathrm{O}_{4}-\mathrm{CuNPs}$ were characterised and investigated by $\mathrm{X}$-ray powder diffraction, scanning electron microscopy, transmission electron microscopy, energy dispersive $X$-ray spectroscopy and X-ray photoelectron spectroscopy. Quantitative analysis of glucose was performed using the amperometric $(i-t)$ method, and a plot of current difference versus concentration of glucose was linear in the range $0.5-336 \mu \mathrm{M}$, with a linear correlation coefficient $\left(R^{2}\right)$ of 0.9989 and limit of detection (LOD) of $0.43 \mu \mathrm{M}$. When the linear range was reduced to $0.5-76.5 \mu \mathrm{M}, R^{2}$ and LOD were 0.9997 and $0.17 \mu \mathrm{M}$, respectively. The sensitivity of the sensor was evaluated as $3.58 \times 10^{4}$ and $4.03 \times 10^{4} \mu \mathrm{A} \mu \mathrm{M}^{-1} \mathrm{~cm}^{-2}$ for the above two linear ranges, respectively. This novel sensor produced satisfactory reproducibility and stability and was applied to monitor trace amounts of glucose in human serum samples.
\end{abstract}

\section{Introduction}

Glucose is one of the most important and widely used aldohexoses in living bodies. One possible reason for this condition is that glucose is less likely to react non-specifically with the amine groups of proteins compared with other aldohexoses. ${ }^{1}$

Diabetes is one of the metabolic diseases characterised by high blood sugar levels for long periods. High blood sugar symptoms, such as frequent urination and increased thirst and hunger, will be observed. When left untreated, serious longterm complications, mainly including cardiovascular disease, stroke, chronic nephropathy, foot ulcers and damage to the eyes, may significantly cause increased morbidity and mortality among diabetics and bring about severe economic burden for individuals and countries. ${ }^{2}$ To monitor blood sugar level accurately, tremendous efforts have been exerted for developing glucose sensors with high sensitivity, good selectivity, easy operation and inexpensiveness. ${ }^{3-6}$ Basing on electroanalytical techniques, researchers studied and developed a number of glucose enzyme biosensors. However, enzymatic activity is susceptible to environmental temperature, atmospheric

${ }^{a}$ College of Chemistry, Nanchang University, Nanchang 330031, China. E-mail: linxiaoyun@ncu.edu.cn; ynni@ncu.edu.cn; Fax: +86791 83969500; Tel: +86 791 83969500

${ }^{b}$ State Key Laboratory of Food Science and Technology, Nanchang University, Nanchang 330047, China

'School of Chemistry, Physics and Mechanical Engineering, Queensland University of Technology, Brisbane 4001, Australia humidity, $\mathrm{pH}$ value and toxic chemicals. ${ }^{7-9}$ The use of enzymes is usually very expensive, and enzyme-based sensing requires either non-physiological electron mediators or oxygen.

As expected, studies on glucose non-enzymatic electrochemical sensors have focused on noble metals and transition metals. ${ }^{10-19}$ These non-enzymatic sensors can overcome the disadvantage of enzyme-based sensors, but some problems in practical application, such as low sensitivity and poor selectivity, still exist. Nano-composites generally exert synergistic effects, and significantly enhance electrocatalytic performance compared with single-component ones, receiving increasing interest in recent years. ${ }^{3-6,18-21}$

Cobalt tetroxide $\left(\mathrm{Co}_{3} \mathrm{O}_{4}\right)$ is an important transition metal oxide and magnetic p-type semiconductor due to its low cost, good chemical stability and considerably high specific capacitance. This compound has been extensively investigated for application in photocatalysis ${ }^{22}$ super capacitors ${ }^{23}$ lithium-ion batteries $^{24,25}$ and electrochemical sensors. ${ }^{26,27}$ Recently, sensors based on $\mathrm{Co}_{3} \mathrm{O}_{4}$ nanomaterial, which exhibits improved stability and catalytic performance especially for detecting glucose and hydrogen peroxide, have attracted considerable attention. Reported works ${ }^{28-30}$ showed that $\mathrm{Co}_{3} \mathrm{O}_{4}$ and copper nano-structures possess highly reversible capacity, good cycling stability and high rate capability.

The aims of this study were as follows: (1) to produce stable mixed films of CuNPs $/ \mathrm{Co}_{3} \mathrm{O}_{4}$ composite by dropping and potentiostatic deposition methods, (2) to investigate electrochemical and electrocatalytic performance of CuNPs $/ \mathrm{Co}_{3} \mathrm{O}_{4} / \mathrm{Pt}$ with the use of cyclic voltammetry (CV) and amperometric 
methods and (3) to develop an excellent quantitative method for detection of glucose in $\mathrm{CuNPs} / \mathrm{Co}_{3} \mathrm{O}_{4} / \mathrm{Pt}$ with the use of amperometric $(i-t)$ technique.

\section{Experimental}

\subsection{Reagents}

Glucose (A.R.), $\mathrm{Co}\left(\mathrm{NO}_{3}\right)_{2} \cdot 6 \mathrm{H}_{2} \mathrm{O}$ (A.R., >99.9\%), polyethylene glycol $\left(\mathrm{HO}\left(\mathrm{CH}_{2} \mathrm{CH}_{2} \mathrm{O}\right)_{n} \mathrm{H}\right)(M=20000)$ and $n$-butyl alcohol $\left(\mathrm{CH}_{3} \mathrm{CH}_{2} \mathrm{CH}_{2} \mathrm{CH}_{2} \mathrm{OH}\right)$ (A.R., 99.9\%) were obtained from Aladdin Chemistry Co., Ltd, Shanghai, China; Human serum samples were supplied by clinical laboratory of the second affiliated hospital of Nanchang University; All other chemicals (A.R.) were obtained from Beijing Chemical Reagent Co., China and used without further purification. Double-distilled water was used throughout experiments.

\subsection{Instrumentation}

Electroanalysis experiments were performed with the use of electrochemical workstation (CHI-660A, Chenhua Apparatus Co., Shanghai). Electrode potentials were reported with respect to the saturated calomel electrode (SCE). A cell stand (Model BAS-C1A) was used to stir test solution for voltammetric experiments.

Transmission electron microscopy (TEM) and energy dispersive X-ray spectroscopy (EDS) were performed to characterise morphology and chemical composition of prepared nanomaterials with the use of a JEM-2010 (JEOL Co., Japan). Associated point and linear resolutions measured 0.23 and $0.14 \mathrm{~nm}$, respectively. Accelerating voltage was set at $200 \mathrm{kV}$.

Scanning electron microscopy (SEM) images were obtained using Quanta 200F instrument (FEI Co. Ltd., Tokyo, Japan) with a power level of $20 \mathrm{kV}$. Test samples were obtained by electrodeposition or dropping onto detachable Pt electrode.

X-ray diffraction data (XRD) were recorded with the use of a Bede Scientific Instrument (Bede D1 System, Durham, UK) using $\mathrm{Cu} \mathrm{K}_{\alpha}$ radiation $(\lambda=1.5406)$ and a Bragg angle range of $10^{\circ}-70^{\circ}$

X-ray photoelectron spectroscopy (XPS) measurements were conducted on a VG Escalab-Mark II spectrometer with monoenergetic $\mathrm{Al} \mathrm{K} \alpha$ radiation (Thermo-VG Scientific Ltd., UK).

\subsection{Preparation of $\mathrm{Co}_{3} \mathrm{O}_{4}$}

An accurately weighed $4.3661 \mathrm{~g} \mathrm{Co}\left(\mathrm{NO}_{3}\right)_{2} \cdot 6 \mathrm{H}_{2} \mathrm{O}$ was dissolved in $10.0 \mathrm{~mL}$ double-distilled water in a $200 \mathrm{~mL}$ beaker, and $15 \mathrm{~mL}$ of polyethylene glycol $\left(\mathrm{HO}\left(\mathrm{CH}_{2} \mathrm{CH}_{2} \mathrm{O}\right)_{n} \mathrm{H}, M=20000,5\right.$ wt\%), $22 \mathrm{~mL}$ of $1.0 \mathrm{~mol} \mathrm{~L}^{-1} \mathrm{KOH}$ and $8.0 \mathrm{~mL}$ of $30 \% \mathrm{H}_{2} \mathrm{O}_{2}$ were slowly added sequentially under stirring conditions. After continuous stirring for $30 \mathrm{~min}$, the mixture was then transferred to a $100 \mathrm{~mL}$ Teflon-lined stainless-steel autoclave, and $15 \mathrm{~mL}$ of $n$ butyl alcohol was added to seal the mixture and reacted at $160{ }^{\circ} \mathrm{C}$ for $16 \mathrm{~h}$. The mixture was then allowed to cool, and black precipitate for each composite sample was collected by centrifugation, successively washed thrice with double-distilled water and ethanol and dried in a vacuum oven at $80{ }^{\circ} \mathrm{C}$ for $8 \mathrm{~h}$. The product was ground into fine powder by an agate mortar.

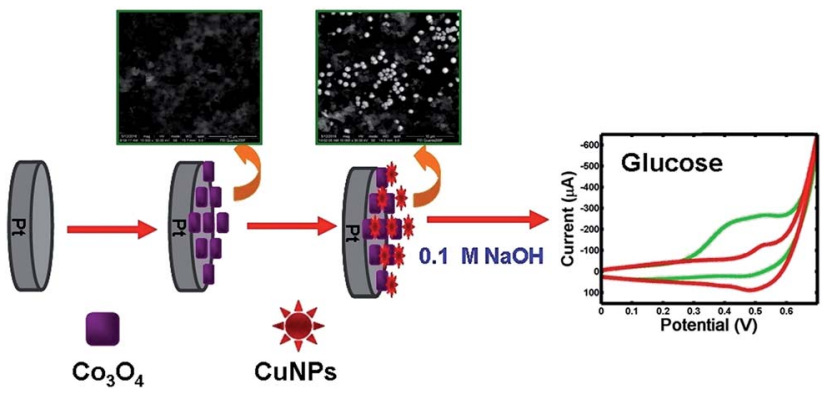

Scheme 1 Schematic representation of fabrication of $\mathrm{CO}_{3} \mathrm{O}_{4}-\mathrm{CuNPs/}$ $\mathrm{Pt}$ and possible reaction mechanism of glucose at the modified GCE.

\subsection{Preparation of $\mathrm{Co}_{3} \mathrm{O}_{4}-\mathrm{CuNPs} / \mathrm{Pt}$}

Pt electrodes (Pt, $3 \mathrm{~mm}$ diameter) were polished with emery paper and alumina slurry (particle size: 1.0, 0.3, and $0.05 \mu \mathrm{m}$ ); they were then successively treated with nitric acid (1:1), ethanol and distilled water by means of ultrasonic cleaning. These electrodes were then immersed in $0.50 \mathrm{~mol} \mathrm{~L}^{-1}$ sulfuric acid solution and electrochemically scanned by cyclic voltammetry (potential range: $-1.0-1.0 \mathrm{~V}$ ) until a steady voltammogram was obtained.

$\mathrm{Co}_{3} \mathrm{O}_{4}$ nanoparticles $(10.0 \mathrm{mg})$ were added to $10.0 \mathrm{~mL} \mathrm{~N}, \mathrm{~N}$ dimethyl formamide (DMF) and treated by an ultrasonic dispersion method for $2 \mathrm{~h}$. Dispersion was stabilised for three weeks. A $20 \mu \mathrm{L}$ sample of this suspension was deposited on the surface of Pt electrode, and the solvent was evaporated naturally in air. A stable film of $\mathrm{Co}_{3} \mathrm{O}_{4}$ nanoparticles then formed on the surface of Pt without protection of Nafion or chitosan. $\mathrm{Co}_{3} \mathrm{O}_{4} / \mathrm{Pt}$ electrode surface was rinsed with double-distilled water to avoid any possible effects of DMF residuals before the following experiments.

$\mathrm{Co}_{3} \mathrm{O}_{4} / \mathrm{Pt}$ electrode was then submitted to successive potential scans (10 times) from $-0.50 \mathrm{~V}$ to $1.50 \mathrm{~V}$ with a scan rate of $0.1 \mathrm{~V} \mathrm{~s}^{-1}$ in mixed solutions, including $5.0 \times 10^{-4} \mathrm{~mol} \mathrm{~L}^{-1}$ $\mathrm{CuSO}_{4}, 0.1 \mathrm{~mol} \mathrm{~L}^{-1} \mathrm{Na}_{2} \mathrm{SO}_{4}$ and $0.01 \mathrm{~mol} \mathrm{~L}^{-1} \mathrm{H}_{2} \mathrm{SO}_{4}$. Finally, the obtained $\mathrm{Co}_{3} \mathrm{O}_{4}-\mathrm{CuNPs} / \mathrm{Pt}$ electrode was rinsed with doubledistilled water several times. Similarly, CuNPs-modified Pt electrode (CuNPs/Pt) was prepared following the above method. Scheme 1 illustrates establishment process of the modified electrode. The $\mathrm{Co}_{3} \mathrm{O}_{4}-\mathrm{CuNPs} / \mathrm{Pt}$ electrode were kept in cold storage at $4{ }^{\circ} \mathrm{C}$.

\section{Results and discussion}

\subsection{Characterisation of $\mathrm{Co}_{3} \mathrm{O}_{4}$ and $\mathrm{Co}_{3} \mathrm{O}_{4}-\mathrm{CuNPs}$}

TEM can provide further insights into morphology and structural features of synthesised materials. TEM images (Fig. 1A and B) indicated that the synthesised $\mathrm{Co}_{3} \mathrm{O}_{4}$ nanoparticles were approximately cubic, and their average diameter was approximately $15 \mathrm{~nm}$. Fig. 1C and D show high-resolution TEM (HRTEM) image and corresponding selected area electron diffraction (SAED) pattern of cubic $\mathrm{Co}_{3} \mathrm{O}_{4}$, respectively. From the lattice fringes of HRTEM image (Fig. 1C), lattice spacing between adjacent planes measured 0.285 and $0.207 \mathrm{~nm}$, 

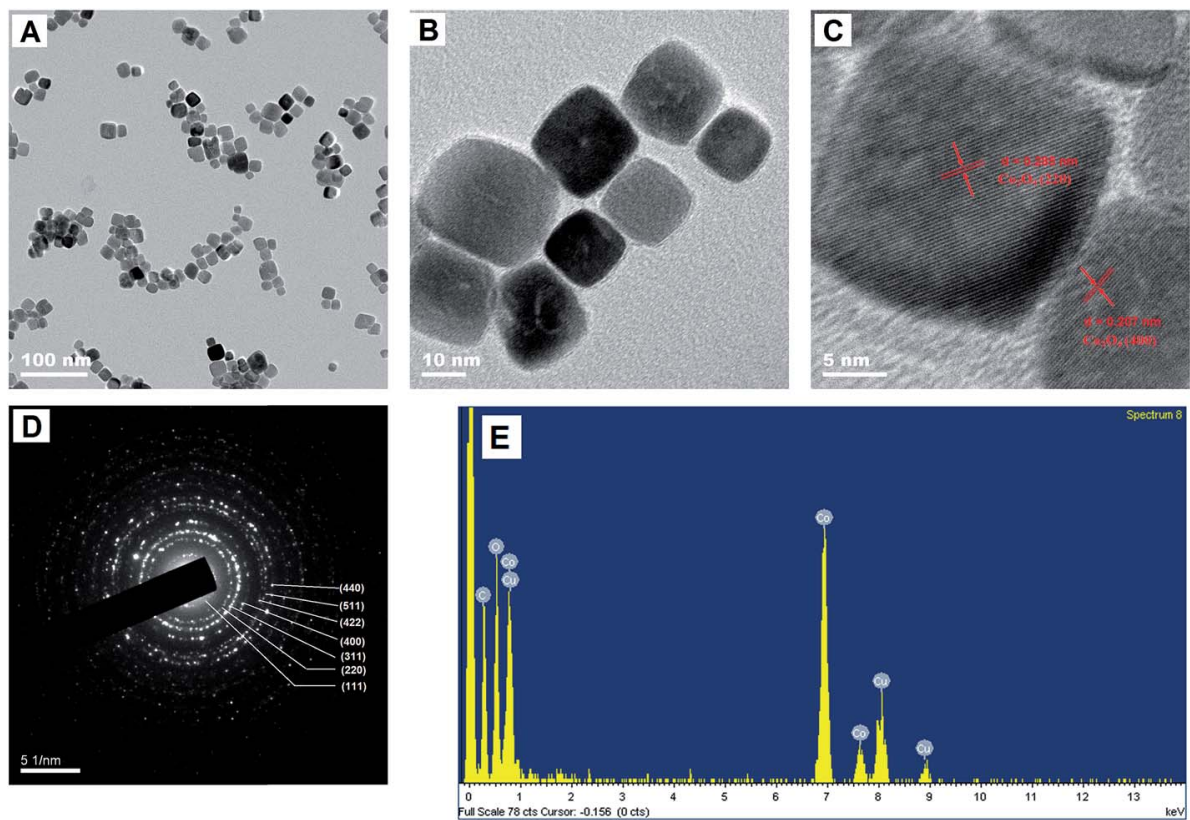

Fig. 1 TEM images (A and B), HRTEM image (C), SAED pattern (D) and EDS (E) of $\mathrm{CO}_{3} \mathrm{O}_{4}$

corresponding to the distance between 220 and 400 lattice planes of cubic $\mathrm{Co}_{3} \mathrm{O}_{4}$ (Fig. 1D). SAED pattern indicated that the synthesised nano-materials is well-crystallised $\mathrm{Co}_{3} \mathrm{O}_{4}$ and was well consonant with XRD results (see experiment below).
EDS test was performed to evaluate chemical composition of $\mathrm{Co}_{3} \mathrm{O}_{4}$ (Fig. 1E) and affirm the existence of $\mathrm{Co}, \mathrm{O}$ and $\mathrm{Cu}$.

Surface composition and chemical states of cubic $\mathrm{Co}_{3} \mathrm{O}_{4}$ were characterised by XPS (Fig. 2A-C). Fig. 2A shows fullinvestigation scan spectrum of $\mathrm{Co}_{3} \mathrm{O}_{4}$ nanoparticles. Only $\mathrm{Co}$
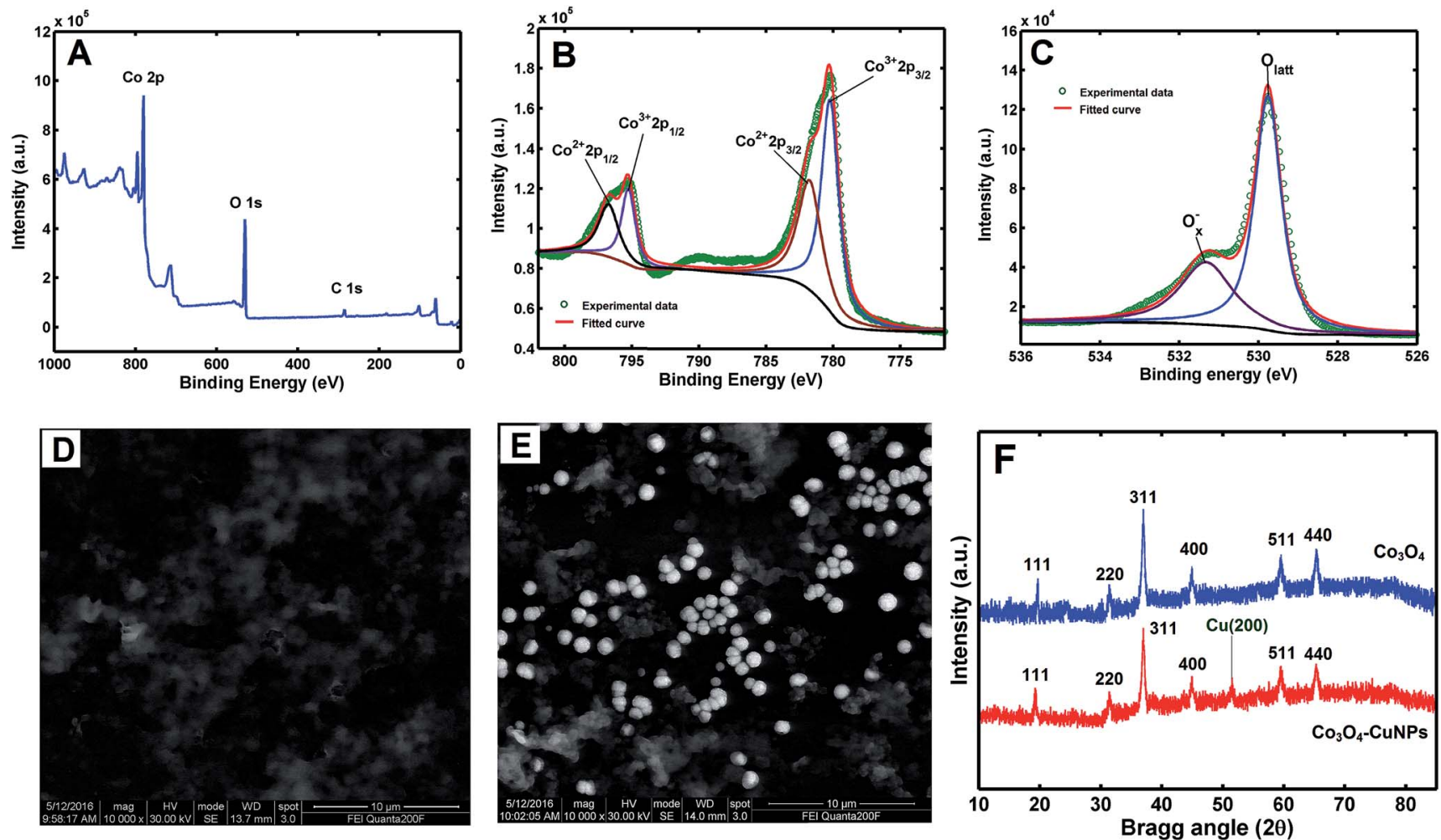

Fig. 2 XPS spectra for scans of $\mathrm{CO}_{3} \mathrm{O}_{4}$ (A), Co $2 \mathrm{p}$ region (B) and O 1 s region (C); SEM images of $\mathrm{Co}_{3} \mathrm{O}_{4} / \mathrm{Pt}(\mathrm{D})$ and $\mathrm{CO} \mathrm{O}_{4}-\mathrm{CuNPs} / \mathrm{Pt}(\mathrm{E}) ; \mathrm{XRD}$ patterns (F) of $\mathrm{CO}_{3} \mathrm{O}_{4}$ and $\mathrm{CO}_{3} \mathrm{O}_{4}-\mathrm{CuNPs}$. 
and $\mathrm{O}$ elements can be observed in XPS full spectrum, confirming high chemical purity of $\mathrm{Co}_{3} \mathrm{O}_{4}$. In this study, the small peak located at $284.5 \mathrm{eV}$ was identified as $\mathrm{C}$ 1s according to references. ${ }^{31,32}$ Typical spectra of Co $2 \mathrm{p}$ and $\mathrm{O} 1 \mathrm{~s}$ binding energies are shown in Fig. $2 \mathrm{~B}$ and $\mathrm{C}$, respectively. As shown in Fig. 2B, Co $2 \mathrm{p}$ core level peaks suggest a highly nonstoichiometric property, indicating that Co atom in the prepared $\mathrm{Co}_{3} \mathrm{O}_{4}$ nanoparticles features two valence states, octahedral $\mathrm{Co}^{3+}$ and tetrahedral $\mathrm{Co}^{2+}$, contributing to the $2 \mathrm{p}$ spectral profile. The main peaks of $\mathrm{Co}^{3+}\left(2 \mathrm{p}_{3 / 2}\right)$ and $\mathrm{Co}^{3+}\left(2 \mathrm{p}_{1 / 2}\right)$ correspond to binding energies of 779.5 and $795.1 \mathrm{eV}$, respectively, and energy difference between the two levels is approximately $15.6 \mathrm{eV}$.

From Fig. 2C, the XPS spectrum of $\mathrm{O} 1 \mathrm{~s}$ for cubic $\mathrm{Co}_{3} \mathrm{O}_{4} . \mathrm{O} 1 \mathrm{~s}$ peak can be fit for two kinds of Gaussian peaks. The main peak at binding energy of $529.7 \mathrm{eV}$ corresponds to oxygen ions in the crystal lattice $\left(\mathrm{O}_{\text {latt }}\right)$, whereas the peak located at $531.3 \mathrm{eV}$ can be attributed to absorbed $\mathrm{O}_{x}{ }^{-}$complex ions (including $\mathrm{O}^{-}$and $\mathrm{O}_{2}{ }^{-}$ ions) in oxygen-deficient regions in the matrix of $\mathrm{Co}_{3} \mathrm{O}_{4} \cdot{ }^{26,33}$

Morphologies of $\mathrm{Co}_{3} \mathrm{O}_{4} / \mathrm{Pt}$ (Fig. 2D) and $\mathrm{Co}_{3} \mathrm{O}_{4}-\mathrm{CuNPs} / \mathrm{Pt}$ (Fig. 2E) were investigated using SEM, and a flocculent and thick structure of $\mathrm{Co}_{3} \mathrm{O}_{4}$ film formed on the Pt electrode surface (Fig. 2D). When CuNPs were electro-deposited on the surface of $\mathrm{Co}_{3} \mathrm{O}_{4} / \mathrm{Pt}$, spherical CuNPs were well distributed on Pt electrode surface (Fig. 1E and inset). Average diameter of these nanoparticles was approximately $200 \mathrm{~nm}$.

Crystallinity and phase structure of prepared material was characterised by XRD. As depicted in Fig. 2F, XRD pattern of $\mathrm{Co}_{3} \mathrm{O}_{4}$ includes seven peaks at approximately $19.2^{\circ}, 31.3^{\circ}, 36.8^{\circ}$, $44.7^{\circ}, 55.7^{\circ}, 59.4^{\circ}$ and $65.2^{\circ}$, which are attributable to $\mathrm{Co}_{3} \mathrm{O}_{4}$ (111), (220), (311), (400), (422), (511) and (440), respectively; ${ }^{27}$ the peak at approximately $50.5^{\circ}$ confirms the presence of CuNPs (200). ${ }^{4}$ These observations suggest successful preparation of $\mathrm{Co}_{3} \mathrm{O}_{4}$-CuNPs nano-composite.

\subsection{Optimisation of main experimental conditions for detecting glucose}

Electrochemical response to glucose $(50.0 \mu \mathrm{M})$ at the $\mathrm{Co}_{3} \mathrm{O}_{4}-$ CuNPs/Pt was evaluated in $0.10 \mathrm{M} \mathrm{NaOH}$ solution at the applied potential from $0.2 \mathrm{~V}$ to $0.6 \mathrm{~V}$ (Fig. 3A). Maximum current change of glucose was obtained at the potential of $+0.50 \mathrm{~V}$, which was consequently selected for subsequent amperometric $i-t$ measurements.

The influence of $\mathrm{NaOH}$ concentration on determination of $50.0 \mu \mathrm{M}$ glucose at $\mathrm{Co}_{3} \mathrm{O}_{4}-\mathrm{CuNPs} / \mathrm{Pt}$ was also investigated (Fig. 3B) at the applied potential of $+0.5 \mathrm{~V}$. Maximum current change for glucose showed no significant difference, whereas $\mathrm{NaOH}$ concentration changed from $0.10 \mathrm{M}$ to $0.30 \mathrm{M}$. Thus, a relatively low concentration of $0.10 \mathrm{M}$ of $\mathrm{NaOH}$ was selected for the following experiment.

\subsection{Electro-catalysis of $\mathrm{Co}_{3} \mathrm{O}_{4}-\mathrm{CuNPs} / \mathrm{Pt}$ for glucose}

Electrochemical properties of glucose in $\mathrm{Co}_{3} \mathrm{O}_{4}-\mathrm{CuNPs} / \mathrm{Pt}$ were investigated in $0.1 \mathrm{M} \mathrm{NaOH}$ solution. As shown in Fig. 4A, a couple of sensitive redox peaks can be observed at the potentials of +0.45 and $+0.55 \mathrm{~V}$ in curves, which can be due to redox reactions of $\mathrm{Co}$ and $\mathrm{Cu}$ nanoparticles under alkaline conditions corresponding to the following equations: $:^{34,35}$

$$
\begin{gathered}
\mathrm{Cu}(0)+2 \mathrm{OH}^{-} \rightarrow \mathrm{Cu}(\mathrm{OH})_{2}+2 \mathrm{e}^{-} \\
\mathrm{Cu}(\mathrm{OH})_{2}+\mathrm{OH}^{-} \rightarrow \mathrm{CuOOH}+\mathrm{H}_{2} \mathrm{O}+\mathrm{e}^{-} \\
\mathrm{Co}_{3} \mathrm{O}_{4}+\mathrm{H}_{2} \mathrm{O}+\mathrm{OH}^{-} \rightarrow 3 \mathrm{CoOOH}+\mathrm{e}^{-} \\
\mathrm{CoOOH}+\mathrm{OH}^{-} \rightarrow \mathrm{CoO}_{2}+\mathrm{H}_{2} \mathrm{O}+\mathrm{e}^{-}
\end{gathered}
$$

Redox peak currents were directly proportional to the potential scan rate $(v)$ in the range of $0.02-0.22 \mathrm{~V} \mathrm{~s}^{-1}$ (Fig. 4B) and increased linearly with the square root of scan rate $\left(v^{1 / 2}\right)$ in the range of $0.24-0.50 \mathrm{~V} \mathrm{~s}^{-1}$ (Fig. 4C). These findings indicate that electrochemical process of $\mathrm{Co}_{3} \mathrm{O}_{4}-\mathrm{CuNPs} / \mathrm{Pt}$ was mainly controlled by adsorption with low-speed scanning (0.02-0.22 V $\mathrm{s}^{-1}$ ), and diffusion-controlled process was observed when scanning rate was in the range of $0.24-0.50 \mathrm{~V} \mathrm{~s}^{-1} .^{3}$

Fig. 4D shows CVs of $\mathrm{Co}_{3} \mathrm{O}_{4}-\mathrm{CuNPs} / \mathrm{Pt}$ in $0.1 \mathrm{M} \mathrm{NaOH}$ without (curve a) and with (curve b) $50.0 \mu \mathrm{M}$ glucose. The figure shows that oxidation peak current increased significantly after addition of $50.0 \mu \mathrm{M}$ glucose. Catalytic currents increased linearly with concentration of glucose (Fig. $4 \mathrm{E}$ ) in the range of $0 \mu \mathrm{M}$ to $50.0 \mu \mathrm{M}$ at $5 \mu \mathrm{M}$ interval.

To investigate electrochemical performance of differently modified electrodes, amperometric $(i-t)$ curves of modified
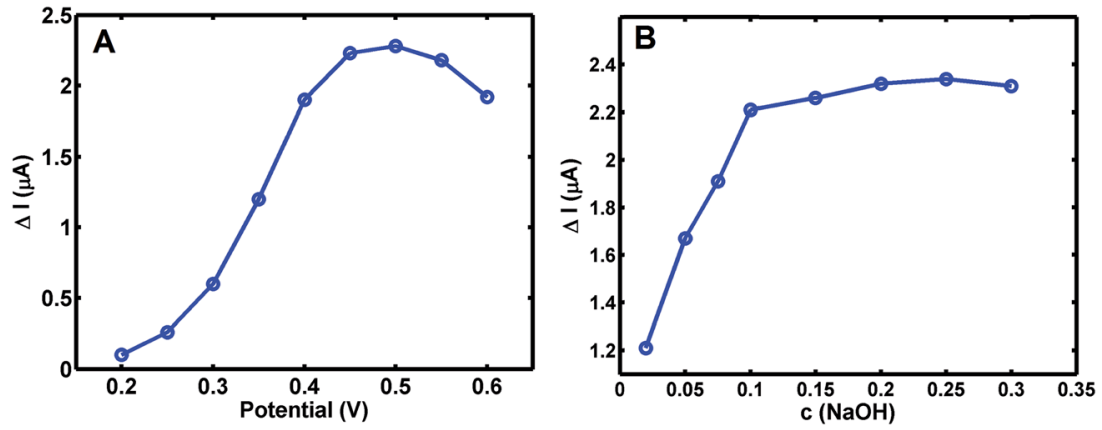

Fig. 3 Influence of different applied potential (A) and pH (B) on $\mathrm{CO}_{3} \mathrm{O}_{4}-\mathrm{CuNPs} /$ Pt sensor added with $50.0 \mu \mathrm{M}$ glucose. 

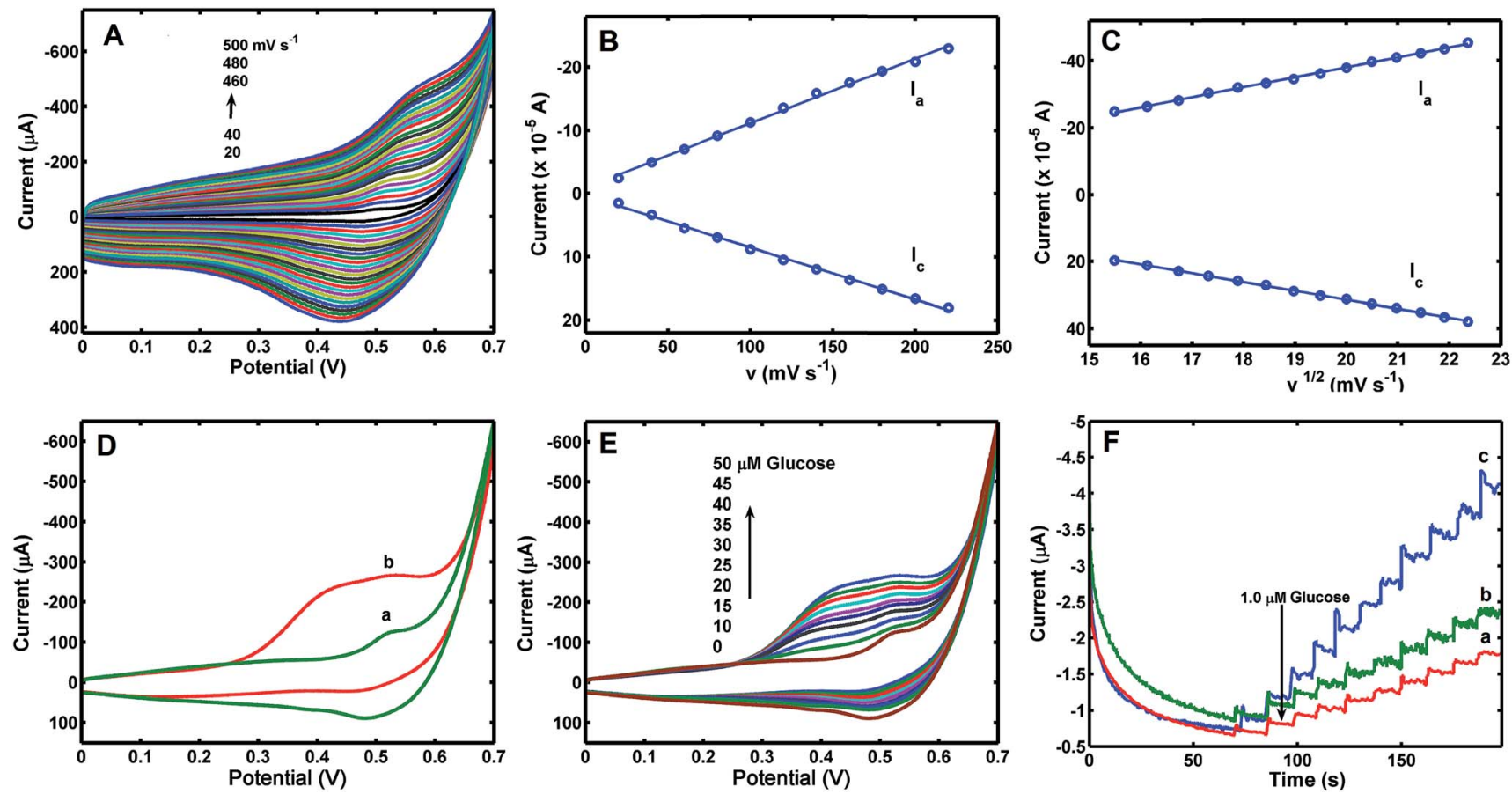

Fig. $4 \mathrm{CV}$ curves of $\mathrm{CO}_{3} \mathrm{O}_{4}-\mathrm{CuNPs} / \mathrm{Pt}$ measured at different scan rates in $0.1 \mathrm{M} \mathrm{NaOH}$ solution (A); plots of redox peak currents versus scan rate (B) and square root of scan rate (C); $\mathrm{CVs}$ of $\mathrm{CO}_{3} \mathrm{O}_{4}-\mathrm{CuNPs} / \mathrm{Pt}$ in (a) absence and (b) presence of glucose in $0.1 \mathrm{M} \mathrm{NaOH}$ solution at $0.10 \mathrm{~V} \mathrm{~s}{ }^{-1}$ (D and E); amperometric response (F) recorded for $\mathrm{CO}_{3} \mathrm{O}_{4} / \mathrm{Pt}(\mathrm{a})$, CuNPs/Pt (b) and $\mathrm{CO}_{3} \mathrm{O}_{4}-\mathrm{CuNPs} / \mathrm{Pt}$ (c).

electrodes were recorded with continuous stirring and successive step changes in glucose at $+0.50 \mathrm{~V}$ in $0.1 \mathrm{M} \mathrm{NaOH}$ (as shown in Fig. $4 \mathrm{~F}$ ). Results indicate that $\mathrm{Co}_{3} \mathrm{O}_{4} / \mathrm{Pt}$ and CuNPs/Pt can also catalyse glucose (curves a and b, respectively, Fig. $4 \mathrm{~F}$ ), but a much larger catalytic current was observed at the $\mathrm{Co}_{3} \mathrm{O}_{4^{-}}$ CuNPs/Pt when $\mathrm{Co}_{3} \mathrm{O}_{4}$ and CuNPs were combined (c, Fig. $4 \mathrm{~F}$ ). This significant improvement can be attributed to synergistic catalytic effects of $\mathrm{Co}_{3} \mathrm{O}_{4}$ and CuNPs. Similar to previous studies, ${ }^{34,35}$ electrochemical reactions for glucose were possibly the following:

$$
\begin{gathered}
\mathrm{CuOOH}+\text { glucose } \stackrel{\mathrm{OH}^{-}}{\longrightarrow} \mathrm{Cu}(\mathrm{OH})_{2}+\text { gluconolactone } \\
\mathrm{CoO}_{2}+\text { glucose } \stackrel{\mathrm{OH}^{-}}{\longrightarrow} \mathrm{CoOOH}+\text { gluconolactone }
\end{gathered}
$$

In $0.1 \mathrm{M} \mathrm{NaOH}$ solution, CuNFs and $\mathrm{Co}_{3} \mathrm{O}_{4}$ can easily transform into $\mathrm{Cu}(\mathrm{OH})_{2}$ and $\mathrm{CoOOH}$, respectively, and under high potential conditions $(+0.5 \mathrm{~V}), \mathrm{Cu}(\mathrm{OH})_{2}$ and $\mathrm{CoOOH}$ can further be oxidised to generate a large number of $\mathrm{CuOOH}$ and $\mathrm{CoO}_{2}$ intermediate products, which can oxidise glucose to gluconolactone.

Chronocoulometric results obtained from the reduction of 5 $\times 10^{-3} \mathrm{~mol} \mathrm{~L}^{-1} \mathrm{~K}_{3}\left[\mathrm{Fe}(\mathrm{CN})_{6}\right]$ in $\mathrm{KCl}\left(0.1 \mathrm{~mol} \mathrm{~L}^{-1}\right)$ at different electrodes, were used to compare the apparent electrode areas with the use of eqn (1): ${ }^{9}$

$$
Q=\left(2 n F A D_{0}{ }^{1 / 2} \pi^{-1 / 2} C_{0}\right) t^{1 / 2}
$$

where $Q$ - the absolute value of the reduction charge, $n$ - the number of electrons transferred, $F$ - the Faraday constant, $A$ - the apparent electrode area, $t$ - the time, and $D_{0}$ and $C_{0}$ - the diffusion coefficient and the bulk concentration of the oxidized form of the hexacyanoferrate (III) complex, respectively.

The apparent electrode area, $A$, may be estimated from the slope of the $Q$ versus $t^{1 / 2}$ plot (Fig. 5). Thus, the order of the slope values was: $\mathrm{Co}_{3} \mathrm{O}_{4}-\mathrm{CuNF} / \mathrm{Pt}(\mathrm{d})>\mathrm{CuNFs} / \mathrm{Pt}(\mathrm{b})>\mathrm{Co}_{3} \mathrm{O}_{4} / \mathrm{Pt}(\mathrm{c})>\mathrm{Pt}$ (a), i.e. $\mathrm{Co}_{3} \mathrm{O}_{4}-\mathrm{CuNF} / \mathrm{Pt}$ has the largest $A$ value, and thus, this modified electrode showed the best electrochemical activity.

\subsection{Quantitative analysis of glucose}

Quantitative analysis of glucose was performed with the use of amperometric $(i-t)$ technique under optimal experimental conditions (applied potential: $+0.5 \mathrm{~V}$; supporting electrolyte:

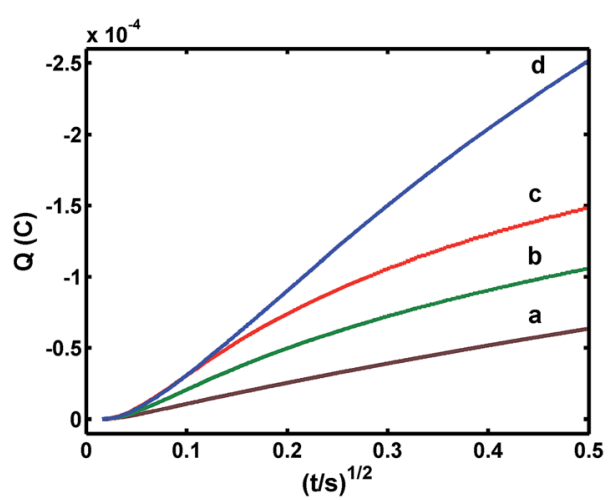

Fig. 5 Chronocoulometric plots from: (a) Pt, (b) $\mathrm{CO}_{3} \mathrm{O}_{4} / \mathrm{Pt}$, (c) CuNPs/ $\mathrm{Pt}$, and (d) $\mathrm{CO}_{3} \mathrm{O}_{4}-\mathrm{CuNFs} / \mathrm{Pt}$ in $5 \times 10^{-3} \mathrm{~mol} \mathrm{~L}^{-1}\left[\mathrm{Fe}(\mathrm{CN})_{6}\right]^{3-14-}(1: 1)$ solution containing $0.1 \mathrm{M} \mathrm{KCl}$. 

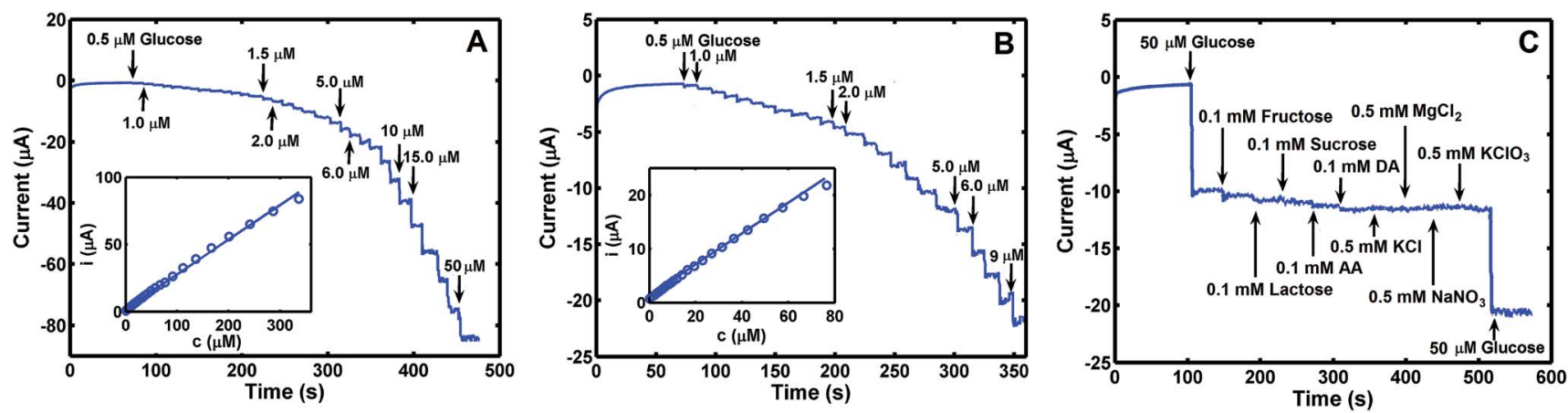

Fig. 6 Amperometric response ( $\mathrm{A}$ and $\mathrm{B}$ ) of $\mathrm{CO}_{3} \mathrm{O}_{4}-\mathrm{CuNPs} / \mathrm{Pt}$ after successive additions of glucose to $0.1 \mathrm{M} \mathrm{NaOH}$ at $+0.50 \mathrm{~V}$. Inset: calibration plot; amperometric response of CuNFs-MoS $2 / G C E$ to different chemicals at $+0.50 \mathrm{~V}$ (C).

Table 1 Results of quantitative analyses of glucose in human serum $(n=3)$

\begin{tabular}{lllllc}
\hline Samples & $\begin{array}{l}\text { Detected } \\
(\mathrm{mM})\end{array}$ & $\begin{array}{l}\mathrm{RSD}^{a} \\
(\%)\end{array}$ & $\begin{array}{l}\text { Added } \\
(\mathrm{mM})\end{array}$ & $\begin{array}{l}\text { Found } \\
(\mathrm{mM})\end{array}$ & $\begin{array}{l}\text { \% recovery } \\
{ }^{b}\end{array}$ \\
\hline$\# 1$ & 5.1 & 3.4 & 2.5 & 7.5 & 98.0 \\
$\# 2$ & 5.3 & 2.8 & 2.5 & 8.0 & 103.8 \\
$\# 3$ & 4.9 & 3.1 & 2.5 & 7.5 & 102.0 \\
$\# 4$ & 5.0 & 2.7 & 2.5 & 7.3 & 96.0
\end{tabular}

${ }^{a}$ RSD (\%) calculated from three separate experiments. ${ }^{b} \%$ recovery $=$ $100 \times\left(c_{\text {found }}-c_{\text {added }}\right) / c_{\text {detected }}$.

$0.1 \mathrm{M} \mathrm{NaOH})$. The plot of current difference versus concentration of glucose was linear in the range of $0.5-336 \mu \mathrm{M}$, with a linear correlation coefficient $\left(R^{2}\right)$ of 0.9989 and limit of detection (LOD) of $0.43 \mu \mathrm{M}$ (Fig. 6A). When linear range was reduced to 0.5-76.5 $\mu \mathrm{M}$, the obtained $R^{2}$ and LOD totalled 0.9997 and $0.17 \mu \mathrm{M}$, respectively (Fig. 6B). Corresponding sensitivity of glucose sensor measured $3.58 \times 10^{4}$ and $4.03 \times 10^{4} \mu \mathrm{A} \mu \mathrm{M}^{-1} \mathrm{~cm}^{-2}$. For analysis of glucose described in this work, performance of this method is comparable with other available methods when comparison is based on $\mathrm{Co}_{3} \mathrm{O}_{4}$-related electrode materials, analytical range, sensitivity and LOD values (see Table 2 ).

Table 2 Comparison of performance of the proposed method for analysis of glucose with results from previously published electrochemical methods based on $\mathrm{CO}_{3} \mathrm{O}_{4}$ nanoparticles

\begin{tabular}{|c|c|c|c|c|}
\hline Electrode materials & $\begin{array}{l}\text { Linear } \\
\text { range } \\
(\mu \mathrm{M})\end{array}$ & $\begin{array}{l}\text { Limit of } \\
\text { detection } \\
(\mu \mathrm{M})\end{array}$ & $\begin{array}{l}\text { Sensitivity } \\
\left(\mu \mathrm{A} \mathrm{mM}^{-1} \mathrm{~cm}^{-2}\right)\end{array}$ & Ref. \\
\hline $\mathrm{Co}_{3} \mathrm{O}_{4}$ UNS-Ni(OH $)_{2}$ & $5-40$ & 1.08 & 2000 & 26 \\
\hline $\mathrm{Co}_{3} \mathrm{O}_{4}$ & $1-500$ & 1 & 366.03 & 37 \\
\hline $\mathrm{Co}_{3} \mathrm{O}_{4}-\mathrm{HND}$ & $2.0-6060$ & 0.58 & 708.4 & 38 \\
\hline $\mathrm{Cu}_{2} \mathrm{O} \mathrm{NCs}-\mathrm{Co}_{3} \mathrm{O}_{4} \mathrm{NHs}$ & $1-5330$ & 0.63 & 280 & 39 \\
\hline $\mathrm{TiO}_{2} / \mathrm{Co}_{3} \mathrm{O}_{4}$ ANTAs & 3000 & 0.34 & 2008.82 & 40 \\
\hline $\mathrm{Co}_{3} \mathrm{O}_{4}$-gold & $0.1-12000$ & 0.0265 & 45.8 & 41 \\
\hline $\mathrm{Co}_{3} \mathrm{O}_{4}-\mathrm{OMC}$ & $10-800$ & 1.0 & 2597.5 & 42 \\
\hline $\mathrm{Co}_{3} \mathrm{O}_{4} / \mathrm{MWCN}$ & $50-12000$ & 10.42 & 5089.1 & 43 \\
\hline $\mathrm{NaCoPO}_{4}-\mathrm{Co}_{3} \mathrm{O}_{4}$ & $1.0-150$ & 0.125 & - & 44 \\
\hline \multirow[t]{2}{*}{$\mathrm{Co}_{3} \mathrm{O}_{4}-\mathrm{CuNPs}$} & $0.5-336$ & 0.43 & 35800 & This \\
\hline & $0.5-76.5$ & 0.17 & 40300 & work \\
\hline
\end{tabular}

\subsection{Interferences, reproducibility and stability}

Anti-interference capacity of this method was investigated using $\mathrm{Co}_{3} \mathrm{O}_{4}-\mathrm{CuNPs} / \mathrm{Pt}$ under the same experimental conditions described above, and different common interfering substances were used, e.g., fructose, sucrose, lactose, dopamine, ascorbic acid, $\mathrm{MgCl}_{2}, \mathrm{KClO}_{3}$ and $\mathrm{NaNO}_{3}$. Current versus time $(i-t)$ plot (Fig. 6C) indicate that these substances produced little interference during analysis of glucose, i.e., the sensor constructed for this work was selective for sensing glucose in the presence of different interfering substances noted above.

To estimate reproducibility and stability of sensor, $\mathrm{Co}_{3} \mathrm{O}_{4}-$ CuNPs/Pt was constructed separately five times with the use of the same Pt electrode. The same concentration of glucose solution $(50.0 \mu \mathrm{M})$ was used as test sample, and results were recorded. Average relative standard deviation (\%RSD) was evaluated as $5.03 \%$ from the five measurement results, which indicated satisfactory reproducibility of the sensor. Sensor stability was estimated by detecting glucose after it was stored at $4{ }^{\circ} \mathrm{C}$ for 30 days, and current intensity for glucose decreased by only $5.8 \%$ compared with the original response on glucose sample of $50.0 \mu \mathrm{M}$. Results suggest stability of $\mathrm{Co}_{3} \mathrm{O}_{4}-\mathrm{CuNPs} / \mathrm{Pt}$ sensor.

\subsection{Analytical applications}

The sensor was applied to analyse glucose levels in human serum. ${ }^{36}$ Before the experiment, pre-processed blood samples was 20-fold diluted with $0.1 \mathrm{M} \mathrm{NaOH}$. Above pre-processed blood samples $(0.4 \mathrm{~mL})$ were transferred to an electrochemical cell and diluted to $10.0 \mathrm{~mL}$ with $0.1 \mathrm{M} \mathrm{NaOH}$. Each blood sample was spiked with standard glucose solutions. Then, the proposed method was applied to monitor levels of glucose, and corresponding results (Table 1) showed that the sensor yielded relatively acceptable percentage recoveries, indicating that the proposed method may possess potential for practical applications.

\section{Conclusions}

A highly sensitive and selective non-enzymatic electrochemical glucose sensor, $\mathrm{Co}_{3} \mathrm{O}_{4}-\mathrm{CuNPs} / \mathrm{Pt}$, was successfully constructed to detect glucose at low concentration levels. The sensor 
achieved highly sensitive and stable glucose detection, and this result maybe due to synergistic catalytic effects of $\mathrm{Co}_{3} \mathrm{O}_{4}$ and CuNPs. Such nano-composites generally possess a large specific surface area, effectively supporting a large number of electroactive substances, and thus significantly enhancing proton and electron transfer. To test practical application of this sensor, it was used to monitor trace amounts of glucose in human serum samples. Significantly, results also showed that the sensor achieved relatively acceptable percentage recoveries, indicating that the proposed method may feature potential practical applications.

\section{Conflicts of interest}

There are no conflicts to declare.

\section{Acknowledgements}

The authors gratefully acknowledge the financial support of this study by the National Natural Science Foundation of China (NSFC-31401587), the Natural Science Foundation of Jiangxi Province (20142BAB213009), and the State Key Laboratory of Food Science and Technology of Nanchang University (SKLFZZA 201612).

\section{References}

1 H. F. Bunn and P. J. Higgins, Science, 1981, 231, 222-224.

2 N. Sarwar, P. Gao, S. R. K. Seshasai, R. Gobin, S. Kaptoge, E. Di Angelantonio, E. Ingelsson, D. A. Lawlor, E. Selvin, M. Stampfer, C. D. A. Stehouwer, S. Lewington, L. Pennells, A. Thompson, N. Sattar, I. R. White, K. K. Ray and J. Danesh, Lancet, 2010, 375, 2215-2222.

3 M. Y. Wu, S. J. Meng, Q. Wang, W. L. Si, W. Huang and X. C. Dong, ACS Appl. Mater. Interfaces, 2015, 7, 21089-21094.

4 X. Y. Lin, Y. N. Ni and S. Kokot, Biosens. Bioelectron., 2016, 79, 685-692.

5 H. Min, W. Q. Wu, H. M. Wu, S. F. Wang, C. Q. Feng and Y. Ding, Electroanalysis, 2017, 29, 730-738.

6 T. Wang, Y. A. Yu, H. F. Tian and J. B. Hu, Electroanalysis, 2014, 26, 2693-2700.

7 R. Wilson and A. P. F. Turner, Biosens. Bioelectron., 1992, 7, 165-185.

8 C. M. Wong, K. H. Wong and X. D. Chen, Appl. Microbiol. Biotechnol., 2008, 78, 927-938.

9 X. Y. Lin, Y. N. Ni and S. Kokot, Sens. Actuators, B, 2016, 233, 100-106.

10 J. S. Mu, Y. Wang, M. Zhao and L. Zhang, Chem. Commun., 2012, 48, 2540-2542.

11 L. Wang, X. P. Lu, C. J. Wen, Y. Z. Xie, L. F. Miao, S. H. Chen, H. B. Li, P. Li and Y. H. Song, J. Mater. Chem. A, 2015, 2, 608616.

12 M. L. Xu, Y. H. Song, Y. H. Ye, C. C. Gong, Y. Shen, L. Y. Wang and L. Wang, Sens. Actuators, B, 2017, 252, 1187-1193.

13 L. Wang, J. Yu, Y. Y. Zhang, H. Yang, L. F. Miao and Y. H. Song, ACS Appl. Mater. Interfaces, 2017, 9(10), 90899095.
14 X. H. Niu, X. Li, J. M. Pan, Y. F. He, F. X. Qiu and Y. S. Yan, RSC Adv., 2016, 88, 84893-84905.

15 X. H. Niu, J. M. Pan, F. X. Qiu, X. Li, Y. S. Yan, L. B. Shi, H. L. Zhao and M. B. Lan, Talanta, 2016, 161, 615-622.

16 X. H. Niu, Y. X. Li, J. Tang, Y. L. Hu, H. L. Zhao and M. B. Lan, Biosens. Bioelectron., 2014, 51, 22-28.

17 X. H. Niu, M. B. Lan, H. L. Zhao and C. Chen, Anal. Chem., 2013, 85, 3561-3569.

18 L. T. Hoa, K. G. Sun and S. H. Hur, Sens. Actuators, B, 2015, 210, 618-623.

19 H. Li, C. Y. Guo and C. L. Xu, Biosens. Bioelectron., 2015, 63, 339-346.

20 W. N. Xu, S. G. Dai, X. Wang, X. M. He, M. J. Wang, Y. Xi and C. G. Hu, J. Mater. Chem. B, 2015, 3, 5777-5785.

21 C. Y. Zhou, L. Xu, J. Song, R. Q. Xing, S. Xu, D. L. Liu and H. W. Song, Sci. Rep., 2014, 4, 7328.

22 S. J. Wang and B. P. Zhang, Appl. Catal., A, 2013, 467, 585592.

23 J. H. Jiang, W. D. Shi, S. Y. Song, Q. L. Hao, W. Q. Fan, X. F. Xia, X. Zhang, Q. Wang, C. B. Liu and D. Yan, J. Power Sources, 2014, 248, 1281-1289.

24 Y. H. Dou, J. T. Xu, B. Y. Ruan, Q. N. Liu, Y. D. Pan, Z. Q. Sun and S. X. Dou, Adv. Energy Mater., 2016, 6, 1501835.

25 C. S. Yan, G. Chen, X. Zhou, J. X. Sun and C. D. Lv, Adv. Funct. Mater., 2016, 26, 1428-1436.

26 Z. F. Gao, L. Q. Zhang, C. Ma, Q. D. Zhou, Y. S. Tang, Z. Q. Tu, W. Yang, L. S. Cui and Y. F. Li, Biosens. Bioelectron., 2016, 80, 511-518.

27 L. Q. Zhang, Z. F. Gao, C. Liu, Y. H. Zhang, Z. Q. Tu, X. P. Yang, F. Yang, Z. Wen, L. P. Zhu, R. Liu, Y. F. Li and L. S. Cui, J. Mater. Chem. A, 2015, 3, 2794-2801.

28 B. B. Wang, G. Wang and H. Wang, Mater. Lett., 2014, 122, 186-189.

29 P. Deka, R. Choudhury, R. C. Deka and P. Bharali, RSC Adv., 2016, 6, 71517-71528.

30 H. Pang, B. Li, Q. X. Zhao, W. Y. Lai and W. Huang, J. Mater. Chem. A, 2016, 4, 4840-4847.

31 J. Li, G. Z. Lu, G. S. Wu, D. S. Mao, Y. L. Guo, Y. Q. Wang and Y. Guo, Catal. Sci. Technol., 2014, 4, 1268-1275.

32 S. J. Deng, N. Chen, D. Y. Deng, Y. X. Li, X. X. Xing and Y. D. Wang, Ceram. Int., 2015, 41, 11004-11012.

33 H. Aono, E. Traversa, M. Sakamoto and Y. Sadaoka, Sens. Actuators, B, 2003, 94, 132-139.

34 L. Wang, Q. Y. Zhang, S. L. Chen, F. G. Xu, S. H. Chen, J. B. Jia, H. L. Tan, H. Q. Hou and Y. H. Song, Anal. Chem., 2014, 86, 1414-1421.

35 K. E. Toghill and R. G. Compton, Int. J. Electrochem. Sci., 2010, 5, 1246-1301.

36 X. Zhong, R. Yuan and Y. Q. Chai, Chem. Commun., 2012, 48, 597-599.

37 S. S. Fan, M. G. Zhao, L. J. Ding, J. J. Liang, J. Chen, Y. C. Li and S. G. Chen, J. Electroanal. Chem., 2016, 775, 52-57.

38 E. H. Zhang, Y. Xie, S. Q. Ci, J. C. Jia and Z. H. Wen, Biosens. Bioelectron., 2016, 81, 46-53.

39 S. Velmurgan, R. Devasenathipathy, S. M. Chen and S. F. Wang, Electroanalysis, 2016, 28, 1547-1552. 
40 M. R. Mahmoudian, W. J. Basirun, P. M. Woi, M. Sookhakian, R. Yousefi, H. Ghadimi and Y. Alias, Mater. Sci. Eng., C, 2016, 59, 500-508.

41 K. Khun, Z. H. Ibupoto, X. Liu, V. Beni and M. Wilander, Mater. Sci. Eng., B, 2015, 194, 94-100.
42 M. Li, C. Han, Y. F. Zhang, X. J. Bo and L. P. Guo, Anal. Chim. Acta, 2015, 861, 25-35.

43 R. Prasad and B. R. Bhat, New J. Chem., 2015, 39, 9735-9742. 44 C. Z. Wei, C. Cheng, J. H. Zhao, X. Yuan, T. T. Wu, Y. Wang, W. M. Du and H. Pang, CrystEngComm, 2015, 17, 4540-4546. 